\title{
GUIDELINES FOR RENAL REPLACEMENT THERAPY IN HIV-INFECTED INDIVIDUALS IN SOUTH AFRICA
}

South African Renal Society, South African Transplant Society, Southern African HIV Clinicians Society

\section{DIALYSIS IN PATIENTS WITH HIV INFECTION}

\subsection{INTRODUCTION}

HIV infection is common in southern Africa and presents our society with numerous challenges. HIV can cause chronic kidney disease (CKD) and can contribute significantly to the burden of patients requiring renal replacement therapy (RRT). HIV-associated nephropathy (HIVAN) was the third commonest cause of end-stage renal failure (ESRF) in black patients in the USA after hypertension and diabetes, ${ }^{1}$ and since the availability of antiretroviral therapy (ART) is now in 7th place. Furthermore HIV infection may coexist with ESRF of any other cause, and we have even

\section{Working Group}

Dr Z Barday (Nephrology, University of Cape Town) Professor A Dhai (Steve Biko Bioethics Centre, University of the Witwatersrand)

Professor R Davids (Nephrology, Stellenbosch)

Dr J Jacobs (Nephrology, Cape Town)

Professor D Kahn (Transplant Surgery, UCT)

Mrs C Kotzenberg (Department of National Health)

Professor M McCulloch (Paediatric Nephrology, UCT)

Dr G Meintjes (Division of Infectious Diseases and HIV

Medicine, UCT)

Dr D Miller (Nephrology, Cape Town; representing SA Transplant Society)

Professor S Naicker (Nephrology, Wits)

Dr I P Naiker (Nephrology, Durban; President SA Renal Society)

Dr C E Ndhlovu (Nephrology, University of Zimbabwe)

Dr W D F Venter (Reproductive Health and HIV Research Unit, Wits)

Dr S Wadee (Nephrology, Wits)

Support Staff (HIV Clinicians Society):

Venie Pillay

Natalie Martyn

Mick Graham

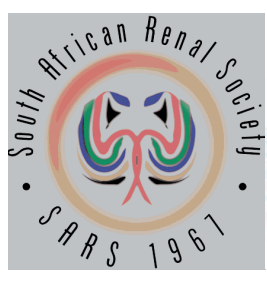

SA Renal Society SA

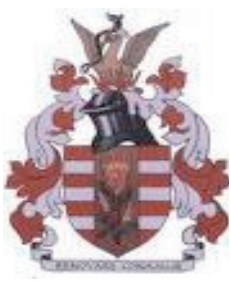

Transplant Society

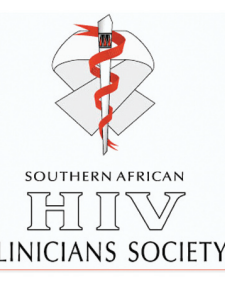

SA HIV Clinicians Society experienced instances of seroconversion to HIV positive of patients already on dialysis.

In southern Africa RRT is not freely available. Patients who can afford it or who have medical insurance may be able to receive these expensive therapies in the private sector in certain countries. The majority, however, do not have access to this service and it is provided to a select few in some state hospitals. Patients are selected for dialysis on the basis of state criteria for acceptance to a transplant programme (Appendix I).

In South Africa, even if patients with ESRF fulfil the state criteria most centres are limited by the availability of 'slots' for dialysis. These are defined by the institution on the basis of availability of funds, staff and equipment. Because the optimal form of RRT is renal transplantation, dialysis is seen as a bridge to transplant and the state 'criteria' are underpinned by the 'transplantability' of the patient. Any guideline on dialysis would have to keep this approach in mind, and the availability of dialysis for HIV-positive patients will be contingent on our ability to transplant them.

These guidelines are primarily aimed at South African clinicians, as limited dialysis and transplant facilities are available to them. There are none in most of the rest of southern Africa, but some countries have embarked on small-scale programmes, and can assess the relevance of the guidelines below to their situation.

\subsection{DIALYSIS IN HIV-POSITIVE PATIENTS}

In the pre-HAART (highly active antiretroviral therapy) era the survival of most patients with advanced HIV infection was dismal. Similarly, for patients with HIV infection on dialysis the outcome was poor even in the developed world. ${ }^{2}$ This led some practitioners to recommend withholding dialysis from these patients. After the advent of antiretrovirals (ARVs), however, several retrospective studies in Europe and the USA confirmed survival rates in the short term that were similar to the non-infected non-diabetic population. ${ }^{3}$ Predictors of poor outcome include: ${ }^{4}$

- Low CD4 counts

- High viral loads

- HIVAN as the cause of ESRF

- Absence of HAART

- Opportunistic infections.

Given the finding that survival of HIV-positive patients receiving HAART is similar to that of non-infected dialysis pa- 
tients, it has been recommended by guidelines in both the USA and the UK that dialysis not be withheld from these patients on the basis of their HIV serostatus., ${ }^{5,6}$ However, the survival of HIV-positive patients on HAART on dialysis is still worse than that of the general HIV-positive population. Studies have shown a more rapid progression of HIV infection in patients with kidney failure, and evidence of kidney disease either in the form of proteinuria or a raised creatinine level portends a poorer outcome for the patient. ${ }^{5}$ This has led to the initiation of transplantation in stable HIV-positive patients, with encouraging early results.

Both haemodialysis (HD) and peritoneal dialysis (PD) have been employed in HIV patients with ESRD. Review of the literature shows that both maintenance $H D$ and $P D$ are effective modes of RRT in these patients, although there are some points of concern with both modalities. ${ }^{6,7}$

\subsubsection{Haemodialysis}

Haemodialysis exposes the dialysis staff to blood products and contaminated needles. It is not necessary to haemodialyse patients in isolation units; the use of universal precautions is the best form of prevention of nosocomial infection.

Dialysis access in the form of an arteriovenous (AV) fistula is the best option for these patients, and similar patency rates to the non-infected population have been shown. ${ }^{6,8}$ Some concern has been raised because of higher rates of polytetrafluoroethylene (PTFE) graft infection in HIV-positive patients, especially those with AIDS. This has led some to avoid permanent access if an AVF cannot be successfully created. However, the use of temporary catheters and permcaths for long-term use often leads to inadequate dialysis, not to mention the risks of infection, vascular occlusion and bleeding. HIV transmission in a dialysis unit has been documented via inadequate sterilisation of re-used needles. ${ }^{9,10}$ Other infections have been caused by breaks in universal precautions and infection control procedures. Guidelines for infection control and machine disinfection set by the Association for the Advancement of Medical Instrumentation and the Centers for Disease Control should be adhered to at all times.

\subsubsection{Peritoneal dialysis (CAPD)}

Theoretically there is less exposure of staff to HIV-infected fluids with PD than with HD because peritoneal fluid is much less infectious than blood, there is less likelihood of a needle stick, and the nature of staff-to-patient contact is different. HIV was shown to survive in PD effluents at room temperature for up to 7 days and in PD exchange tubings for up to 48 hours. Both sodium hypochloride 50\% (Amukin), and household bleach 10\% solutions, in dilutions of 1:512, are effective in killing HIV in dialysate. Patients need to be educated on the need to dispose of these fluids properly. Peritoneal dialysis patients should be instructed to pour dialysate into the home toilet and to dispose of dialysate bags and lines by tying them in plastic bags and disposing of the plastic bags in conventional home garbage. $^{6,11}$
CAPD may aggravate the malnutrition and hypoalbuminaemia in HIV patients with severe wasting syndrome. The rate of peritonitis was also higher in patients with low CD4 counts in the pre-HAART era. Both Gram-positive infections and Pseudomonas infection as well as fungal infections have been reported as being more common."

Overall, given the fact that outcome does not seem to depend on modality of dialysis, the choice of RRT in HIV-infected patients should be based on an individual patient's lifestyle and preferences and availability of family and other support, and not on HIV seropositivity. In South Africa the dialysis modality offered will be further restricted by availability.

The substantial population prevalence of HIV infection (estimated at 6 million), even in a best-case scenario of a $1 \%$ prevalence of HIVAN in the infected population, would mean that 60000 individuals would face this condition, which rapidly progresses to ESRF, without appropriate care. That comes to almost 1200 patients per nephrologist! If only (conservatively again) 10\% progressed to ESRF, this would mean an additional 6000 individuals requiring dialysis - this is more than the current dialysis population in South Africa!

\subsection{CHALLENGES AND RECOMMENDATIONS}

1. Early detection of CKD and prevention of progression to ESRF is of prime importance. The importance of routine screening for kidney disease and appropriate early referral cannot be sufficiently stressed. Evidence indicates that treatment with HAART, angiotensin-converting enzyme (ACE) inhibitors and possibly steroids may slow or arrest progression to ESRF. ${ }^{6}$ Early detection also allows for counselling and preparation of patients for RRT. This includes early initiation of HAART, exploring options for RRT, allowing patients to acquire a medical aid, preemptive transplantation and access creation.

2. Co-infection of these patients with hepatitis $B$ and $C$ may contribute to the burden of renal disease and also complicates therapy. Adequate diagnosis will allow for treatment

3. Drug roll-out issues. To allow adequate access to dialysis, the availability of ARVs to patients with ESRF must be prioritised.

4. Opportunistic infections and malignancies in patients with extremely low CD4 counts may preclude transplantation. This is especially the case with certain infections such as cryptococcosis or malignancies such as Kaposi's sarcoma. (See HIV transplantation guidelines and Department of Health guidelines for other contraindications to renal transplantation.)

5. On the basis of current data we cannot justify excluding patients with HIV infection from receiving dialysis. Patients who are stable on HAART at the time of ESRF should not be treated any differently to other patients, whatever the cause of the ESRF. Similarly, patients in whom HIV infection is coincidental should be started on HAART as soon as possible and dialysis should not be withheld. Patients with advanced HIV disease who present acutely ill will need to be assessed on an indi- 
vidual basis to determine whether dialysis will be offered. This will depend on the following considerations:

- Does the patient have acute reversible renal failure?

What is the short-term prognosis of the patient?

- What is the availability of treatment at the centre?

Would the patient be able to reconstitute his immune system? This may depend on several things including CD4 count, previous HAART, compliance and disease complications.

- Does the patient have a contraindication to renal transplantation, e.g. lymphoma?

\section{GUIDELINES FOR MANAGEMENT OF KIDNEY TRANSPLANTATION IN HIV-INFECTED PATIENTS}

\subsection{INTRODUCTION}

Before the introduction of HAART the morbidity and mortality of HIV-infected patients were considered to be too high to justify using scarce resources in transplanting infected patients. There were concerns that immunosuppression may accelerate HIV replication and result in rapid progression of the disease and increased mortality. Most reports on the effects of immunosuppressive agents (cyclosporine and mycophenalate mofetil) in vitro, on non-transplant HIVinfected patients and in HIV-infected transplant patients, have not shown detrimental effects and have in fact suggested that there may be beneficial effects.

\subsection{MAIN RECOMMENDATIONS}

All HIV-infected patients with CKD should be considered for RRT, including dialysis and transplantation.

Before listing for transplantation HIV-infected patients must demonstrate:

- Stability on HAART therapy with good adherence to treatment for at least 6 months.

absence of current AIDS-defining illness.

- CD4 count $>200 / \mu$ for more than 6 months.

- Paediatric criteria:

- $<1$ year of age - aim to get to 1 year or $10 \mathrm{~kg}$ before transplantation if possible

- 1 - 6 years - CD4\%>25\% (but also consider absolute count)

- $>6$ years $-\mathrm{CD} 4>200$

- Undetectable viral load (<50 copies/ml) for more than 6 months.

\subsection{IMPORTANT CONSIDERATIONS}

It has been well established that compliance with medication and clinic attendance is essential for successful management of both HIV infection and kidney transplantation. It is recommended that:

- Patients must be able and willing to attend close and regular follow-up.

- Patients must be willing to comply with antiviral and antifungal prophylaxis regimens.

- Patients must have a negative pregnancy test and be willing to use effective contraception for at least 2 years post-transplant.
- Women must have annual Pap smears before transplant, as well as mammograms.

- Adolescents will need extra support.

- Patients need to agree to be sent to a centre where a multidisciplinary approach including HIV specialists, nephrologists, dietitian and pharmacology support is available.

\subsection{EXCLUSION CRITERIA}

- Advanced cardiopulmonary disease

- Active uncontrolled malignancy with reduced life expectancy (see national guidelines for solid organ transplantation)

- Significant infection that may flare up or reactivate with immunosuppression (aspergillosis and other fungal infections, severe bacterial disease and active TB)

- Active human papillomavirus infection

- Evidence of liver cirrhosis (especially if co-infected with hepatitis B or hepatitis $C$ virus)

- Untreated hepatitis B or hepatitis C co-infection with active viral replication - consider treatment for hepatitis B or hepatitis C first

- Documented progressive multifocal leukoencephalopathy

- Kaposi's sarcoma

- EBV and human herpesvirus 8 (HHV8)-associated lymphoproliferative diseases

- Active CMV

- Documented poor compliance.

\subsection{HIV-RELATED CRITERIA FOR RENAL DIALYSIS AND TRANSPLANT PROGRAMMES}

HIV infection should not be a reason for exclusion from renal dialysis or renal transplant programmes per se. However, like patients with other medical conditions the HIVinfected patient with ESRD needs to be assessed in terms of co-morbidities and psychosocial factors for suitability for these programmes.

Renal transplantation should only be undertaken in HIV-infected patients when the following criteria are met, in order to optimise the outcome after transplantation:

1. Patient on antiretroviral therapy (ART) for at least 6 months.

2. Adherence to ART is demonstrated and there is a commitment to lifelong therapy.

3. CD4 count $>200$ cells $/ \mu$ l.

4. HIV viral load undetectable.

5. No active opportunistic infections (Ols). If the patient has had a WHO stage 4 infection or TB they should have been fully treated and have been asymptomatic from this infection for at least 6 months.

6. No history of malignancies. However, if the patient has had a previous solid tumour that has been adequately treated and is now in remission they may be considered if they meet criteria for sufficient duration of remission prior to transplantation for HIV-uninfected patients (consult IPTTR prelisting).

7. Absence of certain HIV-related conditions:

a. History of progressive multifocal leucoencephalopathy (PML)

b. History of EBV or HHV-8-associated lymphoprolif- 
erative disorders (lymphoma and multicentric Castleman's disease)

c. History of visceral Kaposi's sarcoma

d. Current advanced human papillomavirus-associated cervical or anal intra-epithelial neoplasia or carcinoma in situ.

Where resources are limited these are the most appropriate patients to consider for dialysis programmes as well. However, where resources permit, even HIV-infected patients who do not fulfil the CD4 and viral load criteria or have had recent Ols, but are committed to starting ART and maintaining adherence, may be considered for dialysis. The majority of such patients will subsequently fulfil these criteria when on ART (and when opportunistic infections have been treated).

In addition, in patients with the conditions described in $7 \mathrm{~b}$ and $7 c$ who are in remission transplantation with subsequent immunosuppressive therapy is inappropriate, but chronic dialysis should be offered for ESRD where possible. This also applies to patients with current advanced human papillomavirus-associated cervical or anal intra-epithelial neoplasia or carcinoma in situ (7d) in whom a transplant could be considered once these conditions have been optimally managed.

\subsection{SOURCE OF ORGANS}

Most units are using both cadaver and live related donors. Because most studies have shown nearly equivalent graft and patient survival with HIV-infected versus non-infected recipients, exclusion of HIV patients from the cadaver list cannot be justified.

Patients should be encouraged to use live related or unrelated donors wherever possible. It is generally considered essential that live donors are fully informed regarding the recipient's HIV status.

It is not currently considered safe to use HIV-infected donors, but little data are available.

\subsection{IMMUNOSUPPRESSIVE PROTOCOLS}

\subsubsection{Induction}

Most studies have shown that HIV-infected patients have at least as frequent and more acute rejection than non-HIV recipients. They should all be considered at 'high immunological risk.' It is considered safe to use monoclonal antibodies (basilixumab or dacluzimab), but polyclonal antibody induction therapy (OKT3) should be avoided. Some studies have had beneficial outcomes using thymoglobulin.

\subsubsection{Maintenance protocols}

It is generally believed that the apparent anti-HIV effects of cyclosporin and mycophenalate mofetil make these preferred first-line immunosuppression together with standard doses of prednisone.

Sirolimus, tacrolimus and azathioprine have been used, but there is very little literature available to support using them as first-line immunosuppression.
Because of interactions between immunosuppressive and antiretroviral drugs, regular drug level monitoring is essential. Once a stable immunosuppressive dose has been achieved the HAART therapy should only be changed under careful supervisison.

\subsubsection{Acute rejection}

A transplant renal biopsy should be considered in all cases of suspected rejection.

Standard high-dose/short-course corticosteroid therapy is considered optimal treatment for acute rejection.

\subsection{TRANSPLANT KIDNEY BIOPSY}

Many transplant units consider it essential to performprotocol biopsies, and units should inform potential recipients before the transplant that this policy may be adopted. Early biopsy may be indicated for delayed graft function or following an acute decline in renal function, but protocol biopsies should be considered at 1, 3 and 12 months.

\subsection{PSYCHOLOGICAL ASSESSMENT AND SUPPORT}

All potential recipients should have a full psychological assessment and identified problems should be managed appropriately. Following the transplant, the recipient, live donor and family may also need further support - this is especially true in adolescent patients.

\subsection{HAART}

Patients must be continued on full therapy following the transplant. It is essential that the transplant unit work with the HIV physician to ensure correct use of all drugs.

- Protease inhibitors (PIs) significantly affect metabolism of cyclosporine, tacrolimus and sirolimus, requiring dose reduction and increased time intervals.

- Efavirenz increases transplant drug requirements.

- Some drugs are antagonistic with mycophenolate and the combination may result in reduced antiviral effects. Stavudine is generally avoided, and zidovudine (AZT) must be used with care, as it shares toxicities with many transplant medications.

- Atazanavir is also usually avoided because of the frequent use of PPIs for acid suppression.

Several published guidelines exist describing interactions between drugs commonly used in HIV-positive recipients and immunosuppressants.

\subsection{SPECIAL CONSIDERATIONS IN CHILDREN}

- Adequate vaccination is important in children especially live virus vaccines - prior to transplantation.

- INH prophylaxis is necessary in high-risk TB areas.

APPENDIX I: NATIONAL SOUTH AFRICAN HEALTH GUIDELINES FOR CHRONIC RENAL DIALYSIS

\section{INTRODUCTION}

It is the aim of the health services of South Africa to provide all South African citizens and permanent residents equita-

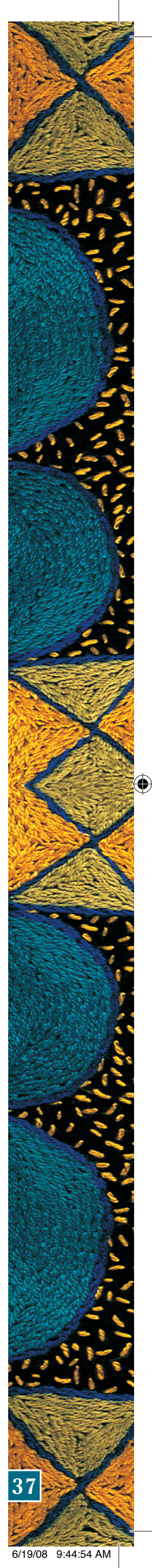


ble access to chronic renal dialysis. Dialysis is a method of removing waste products from the body for patients with kidney failure. The settings where dialysis is undertaken are: Hospitals, satellite units and homes.

These guidelines must therefore be used to make efficient use of limited resources and assist clinicians to decide who should be accepted onto the programme and who should not. Patients who do not satisfy these criteria but who are nevertheless accepted onto a chronic renal dialysis programme in the private sector, should remain the responsibility of the private sector. Kidney transplantation is the choice for many patients, but about a third are not suitable for transplantation and the supply of donor organs is limited.

However, owing to the lack of resources, it has to be accepted that there is a need to set boundaries for medical treatment, including renal dialysis.

\section{OBJECTIVES}

The main objectives of the guidelines are as follows:

- To optimise the use of scarce resources.

- To promote cost-effectiveness.

- To promote public/private partnership.

- To improve services to users.

\section{PRINCIPLES}

Unlike the public sector, renal transplantation should not be the major criterion for acceptance for chronic dialysis in the private sector.

Individual patients with diabetes and patients with acceptable co-morbid conditions may be considered for longterm renal dialysis, although research shows that they do not respond well in the long term.

Patients who satisfy the set criteria and are accepted onto a chronic dialysis programme in the private sector should remain the responsibility of the private sector provider unless there is timeous and specific agreement between the public and private sector to shift the responsibility.

Treatment options for chronic dialysis should be discussed with the patient and the family. They should be allowed to choose the technique that is optimal for the patient with due consideration of medical, social and geographical factors. Treatment that is offered should be cost-effective. In order to make an informed choice the potential impact on the patient's life and that of the family should be explained.

Physical and psychological symptoms related to chronic renal dialysis should be treated appropriately and monitored.

Public-private partnerships should be encouraged as a model for service delivery in chronic renal dialysis.

The service providers must take reasonable measures, within the resources available, to achieve the progressive realisation of the services to be offered.

\section{EXCLUSION RATHER THAN INCLUSION CRITERIA SHOULD BE APPLIED FOR THE SELECTION OF A SUITABLE PATIENT}

Before it is decided that dialysis is a suitable option for an individual, there should be a full assessment of the patient's health care needs such as economic, social, school and work circumstances. The consequences of long-term dialysis for the patient and their family are significant.

\subsection{Medical exclusion criteria}

- Active, uncontrollable malignancy or short life expectancy

- Advanced, irreversible progressive disease of vital organs such as:

- cardiac, cerebrovascular or vascular disease

- advanced cirrhosis and liver disease

- medically or surgically irreversible coronary artery disease

- lung disease

- unresponsive infections e.g. HPV, hepatitis B and C.

2.2 HIV and AIDS are not medical exclusion criteria provided the patient has access to a comprehensive AIDS treatment plan including antiretroviral treatment and has been stable for at least 6 months and the above exclusion factors are absent.

2.3 Age (provided the above exclusion factors are absent) is not a contraindication to chronic renal dialysis. In the UK the median age of starting renal replacement therapy is 63 years and the median age of the population is 54 years.

\subsection{Psychological exclusion criteria}

- Any form of mental illness that has resulted in diminished capacity for patients to take responsibility for their actions.

- Active substance abuse or dependency including tobacco use.

- Obesity.

\subsection{Compliance}

Patients with proven habitual non-compliance with dialysis treatment and lifestyle modification will be excluded or removed from the chronic renal dialysis programme.

\section{APPENDIX II: DIALYSIS REFERENCES}

Ahuja TS, Collinge N, Grady J, Khan S. Is dialysis modality a factor in survival of patients with ESRD and HIV-associated nephropathy? Am J Kidney Dis 2003; 41(5): 1060-1064.

2. Feinfeld DA, Kaplan R, Dressler R, Lynn RI. Survival of human immunodeficiency virus-infected patients on maintenance dialysis. Clin Nephrol 1989; 32(5): $221-$ 224

3. Ahuja TS, Grady J, Khan S. Changing trends in the survival of dialysis patients with human immunodeficiency virus in the United States. J Am Soc Nephrol 2002; 13(7): 1889-1893.

4. Tourret J, Tostivint I, du Montcel ST, et al. I. Outcome and prognosis factors in HIV-infected hemodialysis patients. Clin J Am Soc Nephrol 2006; 1(6): 1241-1247.

5. Bhagani S, Sweny P, Brook G. Guidelines for kidney transplantation in patients with HIV disease. HIV Med 2006; 7(3): 133-139.

6. Gupta SK, Eustace JA, Winston JA, et al. Guidelines for the management of chronic kidney disease in HIV-infected patients: recommendations of the HIV Medicine Association of the Infectious Diseases Society of America. Clin Infect Dis 2005; 40(11): 1559-1585.

7. Soleymanian T, Raman S, Shannaq FN, et al. Survival and morbidity of HIV patients on hemodialysis and peritoneal dialysis: one center's experience and review of the 
literature. Int Urol Nephrol 2006; 38(2): 331-338

8. Ahuja TS, O'Brien WA. Special issues in the management of patients with ESRD and HIV infection. Am J Kidney Dis 2003; 41(2): 279-291.

9. Centers for Disease Control and Prevention. HIV transmission in a dialysis center - Colombia, 1991-1993. JAMA 1995; 274(5): 372-373.

10. Mandayam S, Ahuja TS. Dialyzing a patient with human immunodeficiency virus infection: what a nephrologist needs to know. Am J Nephrol 2004; 24(5): 511-521.

11. Rao TK. Human immunodeficiency virus infection in end-stage renal disease patients. Semin Dial 2003; 16(3): 233-344.

\section{APPENDIX III: TRANSPLANT REFERENCES}

1. Roland ME, Stock PG. Solid organ transplantation is a reality for patients with HIV infection. Curr HIV/AIDS Rep 2006; 3(3): 132-138.

2. Terrault NA Carter JT, Carlson L, Roland ME, Stock PG. Outcome of patients with hepatitis $B$ virus and human immunodeficiency virus infections referred for liver transplantation. Liver Transp/ 2006; 12: 801-807.

3. Stock PG, Roland ME, Carlson L, et al. Kidney and liver transplantation in human immunodeficiency virus-infected patients: a pilot safety and efficacy study. Transplantation 2003; 76(2): 370-375.

4. Roland ME, Lo B, Braff J, Stock PG. Key clinical, ethical, and policy issues in the evaluation of the safety and effectiveness of solid organ transplantation in HIV-infected patients. Arch Intern Med 2003: 163(15): 1773-1778.

5. Roland ME, Carlson LL, Frassetto LA, Stock PG. Review of solid-organ transplantation in HIV-infected patients. Transplantation 2003; 75(4): 425429

6. Roland ME, Stock PG. Comprehensive guidelines translate research findings into clinical policy for HIV-infected transplant candidates and recipients. Enferm Infecc Microbiol Clin 2005; 23(6): 331-334.
Miró JM, Torre-Cisnero J, Moreno A, et al. GESIDA/GESITRA-SEIMC, PNS and ONT Consensus Document on Solid Organ Transplant (SOT) in HIV-Infected Patients in Spain (March, 2005). Enferm Infecc Microbiol Clin 2005; 23(6): 353-362.

8. Halpern SD, Ubel PA, Caplan AL. Solid-organ transplantation in HIV-infected patients. N Engl J Med 2002; 347(4): 284-287.

9. Kumar MS, Sierka DR, Damask AM, et al. Safety and success of kidney transplantation and concomitant immunosuppression in HIV-positive patients. Kidney Int 2005; 67(4): 1622-1629.

10. Abbott KC, Swanson SJ, Agodoa LY, Kimmel PL. Human immunodeficiency virus infection and kidney transplantation in the era of highly active antiretroviral therapy and modern immunosuppress 1639

11. Neff GW, Bonham A, Tzakis $A G$, et al. Orthotopic liver transplantation in patients with human immunodeficiency virus and end-stage liver disease. Liver Transp/ 2003; 9(3): 239-247.

12. Ragni MV, Belle SH, Im K, et al. Survival of human immunodeficiency virusinfected liver transplant recipients. J Infect Dis 2003; 188(10): 1412-1420.

13. Roland ME, Havlir DV. Responding to organ failure in HIV-infected patients. $N$ Eng/ J Med 2003; 348(23): 2279-2281.

14. Roland ME, Adey D, Carlson LL, Terrault NA. Kidney and liver transplantation in HIV-infected patients: case presentations and review. AIDS Patient Care STDS 2003; 17(10): 501-507.

15. Samir K Gupta JA, Eustace JA et al. Guidelines for the Management of Chronic Kidney Disease in HIV-Infected Patients: Recommendations of the H1V Medicine Association of the Infectious Diseases Society of America. Clin Infect Dis 2005. 40(11): 1559-1585.

16. Roland ME, Barin $B$, Carlson L et al. HIV-infected liver and kidney transplant recipients: 1 and 3 year outcomes. Am J Transplant 2008; 8: 355-365.

17. Michelle E, Roland MD, Bernard L, et al. Key clinical, ethical, and policy issues in the evaluation of the safety and effectiveness of solid organ transplantation in HIVinfected patients. Arch Intern Med 2003: 163(15): 1773-1778.

APPENDIX IV. DOSAGE OF ANTIRETROVIRAL DRUGS FOR HIV-INFECTED ADULTS WITH CHRONIC KIDNEY DISEASE (CKD) OR RENAL DISEASE (ESRD) (TABLE 3, DIALYSIS REFERENCE 6, GUPTA SK, et al.)

\begin{tabular}{ll} 
Antiretroviral drug, dosing category & Dosage \\
\hline $\begin{array}{l}\text { Nucleoside reverse transcriptase inhibitors } \\
\text { Zidovudine }\end{array}$ & \\
Usual dosage & $300 \mathrm{mg}$ po bid \\
Dosage for patients with CKD or ESRD & \\
$\quad$ Creatinine clearance $\geq 15 \mathrm{ml} / \mathrm{min}$ & No adjustment \\
Creatinine clearance $<15 \mathrm{ml} / \mathrm{min}$ & $100 \mathrm{mg} \mathrm{po} \mathrm{q} 6-8 \mathrm{~h}$ \\
Receiving haemodialysis & $100 \mathrm{mg} \mathrm{po} \mathrm{q} 6-8 \mathrm{~h}^{+}$ \\
Receiving peritoneal dialysis & $100 \mathrm{mg} \mathrm{po} \mathrm{q} 6-8 \mathrm{~h}$
\end{tabular}

Lamivudine

Usual dosage

Dosage for patients with CKD or ESRD

Creatinine clearance $\geq 50 \mathrm{ml} / \mathrm{min}$

Creatinine clearance $30-49 \mathrm{ml} / \mathrm{min}$

Creatinine clearance $15-29 \mathrm{ml} / \mathrm{min}$

Creatinine clearance $5-14 \mathrm{ml} / \mathrm{min}$

Creatinine clearance $<5 \mathrm{ml} / \mathrm{min}$

Receiving haemodialysis

Receiving peritoneal dialysis

Abacavir ${ }^{\varsigma}$

Usual dosage

Dosage for patients with CKD or ESRD

All creatinine clearances

Receiving haemodialysis

Receiving peritoneal dialysis

Stavudine immediate release (IR)

Body weight $\geq 60 \mathrm{~kg}$

Usual dosage

Dosage for patients with CKD or ESRD

Creatinine clearance $>50 \mathrm{ml} / \mathrm{min}$

Creatinine clearance $26-50 \mathrm{ml} / \mathrm{min}$

Creatinine clearance $\leq 25 \mathrm{ml} / \mathrm{min}$

Receiving haemodialysis

Receiving peritoneal dialysis

Body weight $<60 \mathrm{~kg}$

Usual dosage

Dosage for patients with CKD or ESRD

Creatinine clearance $>50 \mathrm{ml} / \mathrm{min}$

Rating* References

$150 \mathrm{mg}$ po bid/300 po qd

B-I [117-119]

No adjustment

$150 \mathrm{mg}$ po qd

$150 \mathrm{mg}$ po first dose, then $100 \mathrm{mg}$ po qd

$150 \mathrm{mg}$ po first dose, then $50 \mathrm{mg}$ po qd

$50 \mathrm{mg}$ po first dose, then $25 \mathrm{mg}$ po qd

$50 \mathrm{mg}$ po first dose, then $25 \mathrm{mg}$ po qd ${ }^{\dagger}$

$50 \mathrm{mg}$ po first dose, then $25 \mathrm{mg}$ po qd

$300 \mathrm{mg}$ po bid/600 mg po qd

No adjustment

No adjustment ${ }^{\dagger}$

Unknown, use with caution

$30 \mathrm{mg}$ po bid

No adjustment

$20 \mathrm{mg}$ po bid

$20 \mathrm{mg}$ po qd

$20 \mathrm{mg} \mathrm{po} \mathrm{qd}^{+}$

Unknown, use with caution

$30 \mathrm{mg}$ po bid

No adjustment

,




\section{APPENDIX IV. CONTINUED}

\begin{tabular}{ll} 
Antiretroviral drug, dosing category & Dosage \\
\hline Creatinine clearance $26-50 \mathrm{ml} / \mathrm{min}$ & $20 \mathrm{mg}$ po bid \\
Creatinine clearance $\leq 25 \mathrm{ml} / \mathrm{min}$ & $20 \mathrm{mg} \mathrm{po} \mathrm{qd}$ \\
Receiving haemodialysis & $20 \mathrm{mg} \mathrm{po} \mathrm{qd}{ }^{\dagger}$ \\
Receiving peritoneal dialysis & Unknown, use with caution \\
Body weight $<60 \mathrm{~kg}$ & \\
Usual dosage & $30 \mathrm{mg}$ po bid \\
Dosage for patients with CKD or ESRD & No adjustment \\
Creatinine clearance $>50 \mathrm{ml} / \mathrm{min}$ & $15 \mathrm{mg}$ po bid \\
Creatinine clearance $26-50 \mathrm{ml} / \mathrm{min}$ & $15 \mathrm{mg} \mathrm{po} \mathrm{bid}$ \\
Creatinine clearance $\leq 25 \mathrm{ml} / \mathrm{min}$ & $15 \mathrm{mg} \mathrm{po} \mathrm{qd}{ }^{+}$ \\
Receiving haemodialysis & Unknown, use with caution \\
Receiving peritoneal dialysis &
\end{tabular}

Rating* References

Didanosine buffered tablets

Body weight $\geq 60 \mathrm{~kg}$

Usual dosage

Dosage for patients with CKD or ESRD Creatinine clearance $\geq 60 \mathrm{ml} / \mathrm{min}$ Creatinine clearance $30-59 \mathrm{ml} / \mathrm{min}$ Creatinine clearance $10-29 \mathrm{ml} / \mathrm{min}$ Creatinine clearance $<10 \mathrm{ml} / \mathrm{min}$ Receiving haemodialysis Receiving peritoneal dialysis

Body weight $<60 \mathrm{~kg}$

Usual dosage

Dosage for patients with CKD or ESRD Creatinine clearance $\geq 60 \mathrm{ml} / \mathrm{min}$ Creatinine clearance $30-59 \mathrm{ml} / \mathrm{min}$ Creatinine clearance $10-29 \mathrm{ml} / \mathrm{min}$ Creatinine clearance $<10 \mathrm{ml} / \mathrm{min}$ Receiving haemodialysis Receiving peritoneal dialysis

Didanosine EC

Body weight $\geq 60 \mathrm{~kg}$

Usual dosage

Dosage for patients with CKD or ESRD Creatinine clearance $\geq 60 \mathrm{ml} / \mathrm{min}$ Creatinine clearance $30-59 \mathrm{ml} / \mathrm{min}$ Creatinine clearance $10-29 \mathrm{ml} / \mathrm{min}$ Creatinine clearance $<10 \mathrm{ml} / \mathrm{min}$ Receiving haemodialysis Receiving peritoneal dialysis

Body weight $<60 \mathrm{~kg}$

Usual dosage

Dosage for patients with CKD or ESRD Creatinine clearance $\geq 60 \mathrm{ml} / \mathrm{min}$ Creatinine clearance $30-59 \mathrm{ml} / \mathrm{min}$ Creatinine clearance $10-29 \mathrm{ml} / \mathrm{min}$ Creatinine clearance $<10 \mathrm{ml} / \mathrm{min}$ Receiving haemodialysis Receiving peritoneal dialysis

Emtricitabine

Usual dosage

Dosage for patients with CKD or ESRD

Creatinine clearance $\geq 50 \mathrm{ml} / \mathrm{min}$ Creatinine clearance $30-49 \mathrm{ml} / \mathrm{min}$ Creatinine clearance $15-29 \mathrm{ml} / \mathrm{min}$ Creatinine clearance $<15 \mathrm{ml} / \mathrm{min}$ Receiving haemodialysis Receiving peritoneal dialysis

$200 \mathrm{mg}$ po bid

No adjustment

$200 \mathrm{mg}$ po qd

$150 \mathrm{mg}$ po qd

$100 \mathrm{mg}$ po qd

$100 \mathrm{mg} \mathrm{po} \mathrm{qd}^{\dagger}$

$100 \mathrm{mg}$ po qd

$125 \mathrm{mg}$ po bid

No adjustment

$150 \mathrm{mg}$ po qd

$100 \mathrm{mg}$ po qd

$75 \mathrm{mg}$ po qd

$75 \mathrm{mg} \mathrm{po} \mathrm{qd}^{+}$

$75 \mathrm{mg}$ po qd

$400 \mathrm{mg}$ po qd

No adjustment

$200 \mathrm{mg}$ po qd

$125 \mathrm{mg}$ po qd

$125 \mathrm{mg}$ po qd

$125 \mathrm{mg} \mathrm{po} \mathrm{qd}^{\dagger}$

$125 \mathrm{mg}$ po qd

$250 \mathrm{mg}$ po qd

No adjustment

$125 \mathrm{mg}$ po qd

$125 \mathrm{mg}$ po qd

Do not use; use buffered tablets instead

Do not use; use buffered tablets instead

Do not use; use buffered tablets instead

$200 \mathrm{mg}$ po qd

No adjustment

$200 \mathrm{mg}$ po q $48 \mathrm{~h}$

$200 \mathrm{mg}$ po $\mathrm{q} 72 \mathrm{~h}$

$200 \mathrm{mg}$ po q $96 \mathrm{~h}$

$200 \mathrm{mg}$ po $\mathrm{q} 96 \mathrm{~h}^{\dagger}$

Unknown, use with caution 


\section{APPENDIX IV. CONTINUED}

\begin{tabular}{|c|c|c|c|}
\hline Antiretroviral drug, dosing category & Dosage & Rating* & References \\
\hline $\begin{array}{l}\text { Tenofovir } \\
\text { Usual dosage } \\
\text { Dosage for patients with CKD or ESRD } \\
\text { Creatinine clearance } \geq 50 \mathrm{ml} / \mathrm{min} \\
\text { Creatinine clearance } 30-49 \mathrm{ml} / \mathrm{min} \\
\text { Creatinine clearance } 10-29 \mathrm{ml} / \mathrm{min} \\
\text { Receiving haemodialysis } \\
\text { Receiving peritoneal dialysis }\end{array}$ & $\begin{array}{l}300 \mathrm{mg} \text { po qd } \\
\text { No adjustment } \\
300 \mathrm{mg} \text { po q } 48 \mathrm{~h} \\
300 \mathrm{mg} \text { po q } 72 \mathrm{~h} \\
300 \mathrm{mg} \text { po every } 7 \text { days }^{\ddagger} \\
\text { Unknown, use with caution }\end{array}$ & $B-I I$ & {$[128,129]$} \\
\hline $\begin{array}{l}\text { Emtricitabine/tenofovir } \\
\text { Usual dosage } \\
\text { Dosage for patients with CKD or ESRD } \\
\text { Creatinine clearance } \geq 50 \mathrm{ml} / \mathrm{min} \\
\text { Creatinine clearance } 30-49 \mathrm{ml} / \mathrm{min} \\
\text { Creatinine clearance }<30 \mathrm{ml} / \mathrm{min}\end{array}$ & $\begin{array}{l}200 \mathrm{mg} / 300 \mathrm{mg} \text { po qd } \\
\text { No adjustment } \\
\text { One tab po q } 48 \mathrm{~h} \\
\text { Unknown, should not use combination tablet }\end{array}$ & C-III & [130] \\
\hline Non-nucleoside reverse transcriptase i & & & \\
\hline $\begin{array}{l}\text { Nevirapine } \\
\text { Usual dosage } \\
\text { Dosage for patients with CKD or ESRD } \\
\text { Creatinine clearance }>20 \mathrm{ml} / \mathrm{min} \\
\text { Receiving haemodialysis } \\
\text { Receiving peritoneal dialysis }\end{array}$ & $\begin{array}{l}200 \text { mg po bid } \\
\text { No adjustment } \\
\text { No adjustment } \\
\text { Unknown, use with caution }\end{array}$ & $B-I I$ & {$[131-135]$} \\
\hline $\begin{array}{l}\text { Efavirenz } \\
\text { Usual dosage } \\
\text { Dosage for patients with CKD or ESRD }\end{array}$ & $\begin{array}{l}600 \mathrm{mg} \text { po qd } \\
\text { No adjustment }\end{array}$ & C-III & [136-138] \\
\hline $\begin{array}{l}\text { Delavirdine } \\
\text { Usual dosage } \\
\text { Dosage for patients with CKD or ESRD }\end{array}$ & $\begin{array}{l}400 \mathrm{mg} \text { po tid } \\
\text { No adjustment }\end{array}$ & C-III & [139] \\
\hline Protease inhibitors & & & \\
\hline $\begin{array}{l}\text { Indinavir } \\
\text { Usual dosage } \\
\text { Dosage for patients with CKD or ESRD }\end{array}$ & $\begin{array}{l}800 \mathrm{mg} \text { po tid } \\
\text { No adjustment }\end{array}$ & C-III & {$[140,141]$} \\
\hline $\begin{array}{l}\text { Saquinavir soft gel } \\
\text { Usual dosage } \\
\text { Dosage for patients with CKD or ESRD }\end{array}$ & $\begin{array}{l}1200 \mathrm{mg} \text { po tid } \\
\text { No adjustment }\end{array}$ & C-III & {$[132,142,143]$} \\
\hline $\begin{array}{l}\text { Saquinavir hard gel } \\
\text { Usual dosage } \\
\text { Dosage for patients for CKD or ESRD }\end{array}$ & $\begin{array}{l}600 \mathrm{mg} \text { po tid } \\
\text { No adjustment }\end{array}$ & $\mathrm{C}-\mathrm{II}$ & {$[132,142,144]$} \\
\hline $\begin{array}{l}\text { Nelfinavir } \\
\text { Usual dosage } \\
\text { Dosage for patients with CKD or ESRD }\end{array}$ & $\begin{array}{l}1250 \mathrm{mg} \text { po bid } \\
\text { No adjustment }\end{array}$ & C-III & {$[133,145,146]$} \\
\hline $\begin{array}{l}\text { Amprenavir } \\
\text { Usual dosage } \\
\text { Dosage for patients with CKD or ESRD }\end{array}$ & $\begin{array}{l}1200 \mathrm{mg} \text { po bid } \\
\text { No adjustment }\end{array}$ & C-III & {$[147]$} \\
\hline $\begin{array}{l}\text { Fosampenavir } \\
\text { Usual dosage } \\
\text { Dosage for patients with CKD or ESRD }\end{array}$ & $\begin{array}{l}1400 \mathrm{mg} \text { po qd/700 mg po bid } \\
\text { No adjustment }\end{array}$ & C-III & [148] \\
\hline $\begin{array}{l}\text { Ritonavir } \\
\text { Usual dosage } \\
\text { Dosage for patients with CKD or ESRD }\end{array}$ & $\begin{array}{l}600 \mathrm{mg} \text { po bid } \\
\text { No adjustment }\end{array}$ & C-III & {$[135,142,149]$} \\
\hline $\begin{array}{l}\text { Lopinavir/ritonavir } \\
\text { Usual dosage } \\
\text { Dosage for patients with CKD or ESRD }\end{array}$ & $\begin{array}{l}400 \mathrm{mg} / 100 \mathrm{mg} \text { po bid } \\
\text { No adjustment }\end{array}$ & C-III & {$[150,151]$} \\
\hline $\begin{array}{l}\text { Atazanavir } \\
\text { Usual dosage } \\
\text { Dosage for patients with CKD or ESRD }\end{array}$ & $\begin{array}{l}400 \mathrm{mg} \text { po qd } \\
\text { No adjustment }\end{array}$ & C-III & [152] \\
\hline
\end{tabular}


APPENDIX IV. CONTINUED

\begin{tabular}{|c|c|c|c|}
\hline Antiretroviral drug, dosing category & Dosage & Rating* & References \\
\hline \multicolumn{4}{|l|}{ Entry/fusion inhibitors } \\
\hline \multicolumn{2}{|l|}{ Enfuvirtide } & \multirow{5}{*}{\multicolumn{2}{|c|}{ [153] }} \\
\hline Usual dosage & $90 \mathrm{mg} \mathrm{sc}$ bid & & \\
\hline \multicolumn{2}{|l|}{ Dosage for patients with CKD or ESRD } & & \\
\hline Creatinine clearance $\geq 35 \mathrm{ml} / \mathrm{min}$ & No adjustment & & \\
\hline Creatinine clearance $<35 \mathrm{ml} / \mathrm{min}$ & Unknown, use with caution & & \\
\hline \multicolumn{4}{|c|}{ *The rating is for the recommendations on dose adjustment for patients with reduced renal function. } \\
\hline \multicolumn{4}{|c|}{ †ZZidovudine/lamivudine (Combivir; GlaxoSmithKline) should be administered as separate component medications in patients with creatinine clearance <50 m//min. } \\
\hline \multicolumn{4}{|c|}{${ }^{\dagger}$ Administer either the daily dose or one of the daily doses after haemodialysis. } \\
\hline \multicolumn{4}{|c|}{$\begin{array}{l}\text { §Zidovudine/lamivudine/abacavir (Trizivir; GlaxoSmithKline) and lamivudine/abacavir (Epzicom; GlaxoSmithKline) should be administered as separate component medica- } \\
\text { tions in patients with creatinine clearance < } 50 \mathrm{ml} / \mathrm{min} \text {. }\end{array}$} \\
\hline
\end{tabular}

\section{Learning from HIV and AIDS}

\section{SAMA Member Price: R580 Non-member Price : R640}

ISBN: 9780521004701

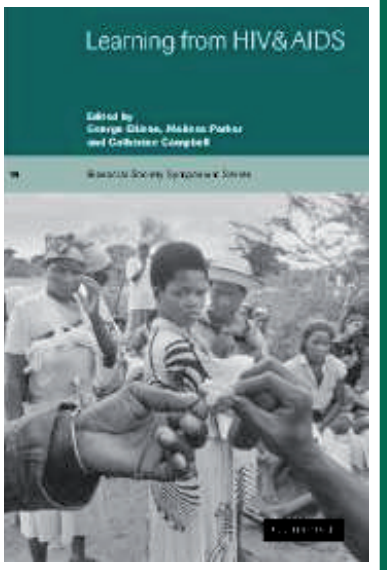

Different professional and academic disciplines have addressed the HIV and AIDS pandemic from a variety of perspectives, using different analytical approaches. By bringing these together in one volume, Learning from HIV and AIDS provides a more complete picture of this multi-faceted disease, from the biological and social factors that facilitate HIV transmission to the powerful cultural and political forces that fuel the pandemic. Chapters from contributors working on the aetiology, treatment and prevention of HIV and AIDS identify how their work has helped predict the spread of HIV and has improved the survival of those infected. Yet interventions to reduce the spread of HIV have had limited success, and few HIV-infected individuals have access to combination drug therapies. Written for students and researchers, and taking a multidisciplinary perspective, this book demonstrates that progress in developing effective and acceptable interventions can only be achieved through interdisciplinary collaboration between the biological, medical and social sciences.

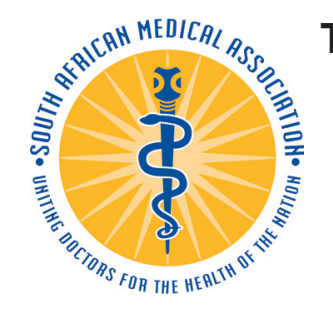

To Order: Health \& Medical Publishing Group, Private Bag X1, Pinelands, 7430 e-mail: tarynen@hmpg.co.za, or carmena@hmpg.co.za

Tel: 021-6578200 or Fax: 021-6834509

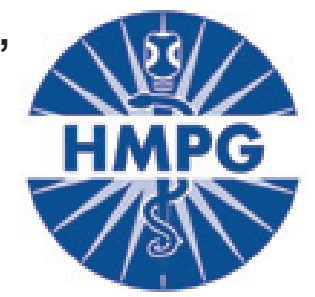

